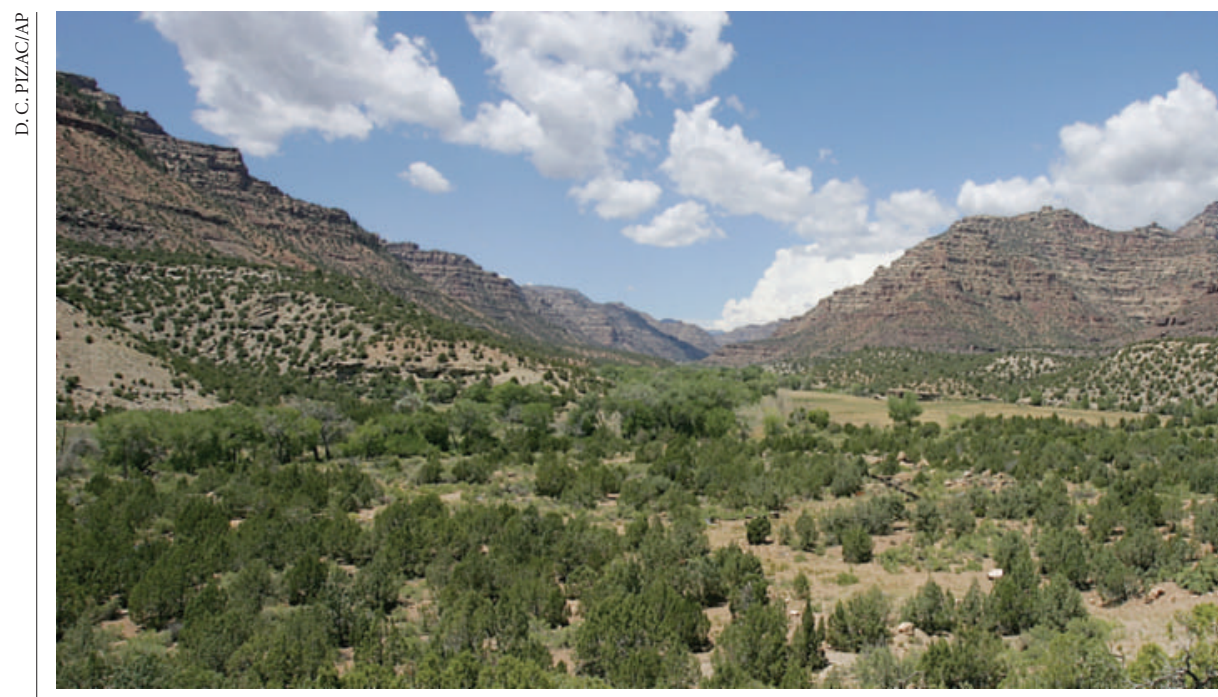

Rich pickings: this ranch in Range Creek features a wealth of undisturbed archaeology.

\title{
Native Americans voice fears for relics in land-transfer deal
}

Rex Dalton, San Diego

Archaeologists are celebrating a 'find of a lifetime' at a Utah ranch packed with ancient relics. But some Native Americans in the area are upset that they were not consulted about how the land should be treated when it first passed into public hands for study some three years ago.

The 1,700-hectare ranch, in Range Creek, Utah, sports countless archaeological sites, most of which are undisturbed. The previous owner of the property, Waldo Wilcox, was well aware of the scientific value of the land - he and his family had maintained the site for more than 50 years. A shotgun-wielding Wilcox would warn off intruders and looters venturing onto his property.

But while rumours of the archaeological value of the site swirled in academic circles for years, it wasn't until 2002 that Utah state archaeologist Kevin Jones toured the ranch and saw its true riches — including dwellings, granaries and rock art dating from between 2,000 and 700 years ago.

Others have likewise been impressed. "I was blown away," says Duncan Metcalfe, curator of archaeology at the Utah Museum of Natural History in Salt Lake City and leader of the site survey. "I've never seen anything like this in my 25 years of archaeology," he adds.

Researchers are now planning studies and consultations with Native American tribal leaders about any future excavations. Such consultations are designed in part to accommodate their beliefs on the handling of human remains, which are often at odds with archaeological study. In the case of the Kennewick Man skeleton found in Washington state, for example, tribes have legally delayed research for eight years for cultural reasons.
But some Native Americans in the Range Creek area — including Melvin Brewster, a Northern Piaute with a doctorate in archaeology — are angry that these consultations are coming so late. They point out that the land has been in government hands for years. In 1998, an organization of hunting and fishing enthusiasts petitioned for federal legislation to buy the ranch, ensuring its availability for sport. The US Bureau of Land Management (BLM) then took title to the land for $\$ 2.5$ million in 2001, conveying it to the state of Utah in January 2004.

Brewster claims that the Utah deal violated federal laws on historic-site planning, environmental policy and protection of Native American remains. Calling the land conveyance an "under-the-table deal", Brewster claims that the BLM had an obligation during the years of federal ownership to consult with tribes about Native American remains and to seek public comment on any plans for the ranch. "The American public has been violated," he says.

Brewster says he worries that Native American relics may not be treated properly now that the land is owned by the state of Utah. He is concerned that insufficient funds may be available to stop looting, for example.

Don Banks, BLM spokesman for the Utah region, says that the deal was done based on special legislation secured by two congressmen from Utah. He adds that no one sought any special legal advice about the transfer.

For now, both Native Americans and scientists are excited about the discoveries expected from the ranch. "I have faith that Utah will lay out a plan to work with all of us," says Leigh Kuwanwisiwma, director of the Hopi Cultural Preservation Office in Arizona.
Project probes impact of waste carbon dioxide on marine life

David Cyranoski, Tokyo

Japanese researchers are beginning to make public the first data from a project that could allow waste carbon dioxide to be dumped in the ocean. The tests are aimed at finding what concentrations of carbon dioxide can be tolerated by worms and bacteria living in the muddy sea floor.

But critics of the scheme say that even the 'safe' limits determined by the project could still be harmful in the long term.

Researchers and industry are interested in pumping waste $\mathrm{CO}_{2}$ down to the sea floor to reduce atmospheric levels of the greenhouse gas. But the idea is

controversial. Recent tests have shown that the rise in oceanic $\mathrm{CO}_{2}$ levels from natural absorption from the air over the next century could have a detrimental effect on sea creatures' ability to make shells (R. A. Feely et al. Science 305, 362-366; 2004). Higher concentrations from dumped $\mathrm{CO}_{2}$ could have an even greater impact.

In the project, conducted by the Research Institute of Innovative Technology for the Earth (RITE) in Kyoto and the research arm of the Kansai Electric Power Company in Osaka, plastic containers were placed on the sea floor off the coast of Japan. Carbon dioxide was then pumped into the containers.

Extremely high concentrations of 20,000 and 5,000 parts per million caused most visible creatures, such as nematodes, to die, the team says, although the abundance of smaller creatures and bacteria was barely affected. Shigeo Murai, the ocean chemist who heads the project, says that RITE is working on technologies to dilute $\mathrm{CO}_{2}$ to concentrations tens of thousands of times lower than those used in the experiments before introducing it to the sea floor. This means it should have no effect on marine life, he says.

But Kenji Kato, a microbial ecologist at Shizuoka University, says that low concentrations could also have an effect in the long term. Even if the number of bacteria stays the same, he says, the species of bacteria present could be changing: "An entirely new community could grow in a few months."

It is also unclear how the $\mathrm{CO}_{2}$ would disperse once it is on the sea floor. Experiments to assess this have been blocked in the past by environmental protesters (see Nature 419,6 ; 2002). Murai plans to look at a natural outlet of $\mathrm{CO}_{2}$ seeping into the ocean floor around Okinawa to study its dispersion. 